\title{
FUNCTIONAL DIFFERENTIATION OF THE BLASTOCYSTIC RING TROPHOBLAST CELLS IN THE RAT
}

\author{
Ramazan Demir \\ Department of Histology and Embryology, Faculty of Medicine, Akdeniz University, Antalya, Turkey
}

\begin{abstract}
- It is accepted that the implantation consists of establishment of contacts between the trophoblast cells of blastocystic ring and the uterine epithelium. Prior to the contact with uterine epithelium the blastocyst undergoes a series of physiological and developmental changes. The formation and differentiation of blastocystic ring and its ultrastructural and cytochemical aspects have been extensively studied (1-21). The stages of blastocystic ring formation, preimplantation, epithelial penetration, and related biochemical events vary significantly among different species of mammals (22).
\end{abstract}

A modern direction in the molecular studies of implantation involves the role of essential elements of inflammation $(5,14$, 15, 22-31). The mutual recognition of the implanting embryo and the uterus is of primary importance in the first stages of implantation. It probably demands establishment of a tight contact between them. It also accounts for the appropriate distribution of cytokines, substrates, and adhesion molecules in the uterus and the embryo. Basic ultrastructural studies on the implantation in rats (18) showed that the critical step of blastocyst attachment to the uterine epithelium, chorioallantoic placenta formation including cell death, extracellular matrix and new vessel formation, and decidual reactions takes place on the 5th day after fertilization $(4,32-36)$.

Biomed Rev 1997; 8: 127-132

Received for publication 25 June 1997 and accepted 28 November 1997. Correspondence and reprint requests to Dr Ramazan Demir.Department of Histology and Embryology, Faculty ofMedicine, Akdeniz University, 07070 Kampus Antalya, Turkey. Tel/Fax: 90 (242) 2274486 or 2274495 , Email: demir@hipokrat.med.akdeniz.edu.tr
The obscurity about cellular identification of blastocystic ring trophoblast cells led us to the assumption that their structural differentiation in the rat is not uniform. They should have some differences in their properties according to the functional performance during the initiation of the blastouterine interaction. A series of studies (37-41) discussed the role of microfilaments in the development of differentiationdependent changes in cell polarity, and a possible signalling between blastomers during the preimplantation period in rodents. In our studies, we described electron microscopically the trophoblast cells with their different shapes and structures, as well as the diversity of blastocystic cells as elliptical or rounded, flattened, lipid droplets-rich, homogenous, and canaliculated. We also found many distinct junction complexes at the apical and lateral boundaries of trophoblast cells.

We have previously shown that during the preimplantation in rats, trophoblast cells show different structural features according to their functional differences $(36,42,43)$. In addition to the dense long-line connection complexes and desmosome-like structures between trophoblast cells, many interdigita-tion-like complexes have been observed. In contrarst to previous studies (44), our results suggest that these complexes are not widened or narrowed, but regularly arranged in parallel, with regular areas and thickness (42). The connected complexes are formed at early stages of embryogenesis, and persist in most tissues throughout the development (45). The trophoblast cells exchange metabolites and ions via specific junctions, and thus coordinate their cellular activities and maintain an uniform tissue phenotype (46). Cells in different regions of a given tissue may be subjected to different homeo- 
static challenges (47-50). The trophoblastic cells in different regions of the ring may not only maintain different cytoplasmic contents of ions and other substances, but also use one and the same molecules for different purposes (50).

Analysis of the patterns of junctional communication (45, 50, 51) in these structures has shown that: (i) cells in the lateral and abembryonic pole regions of the blastocystic ring communicate freely with each other, (ii) trophoblast cells immediately above these regions short-out intercommunication blastomers according to their respective differentiation density, and $(\mathrm{Hi})$ the differentiated trophoblast cells in different poles of the blastocyst remain well coupled within their intercellular areas. According to our studies, the connected complexes between the blastocystic ring cells are three different types. They possess no structural similarities, but may exhibit certain differences in their size. Furthermore, it appears that these three different cell-to-cell communication systems are involved in the molecular and biochemical coordination of the blastocyst trophoblast cells $(44,51,52)$.

Cell-to-cell interactions between the trophoblast and uterine epithelium may take place throughout three stages, (i) recognition and adhesion, (ii) engulfment and establishment, and $(\mathrm{Hi})$ control. In the first stage, trophoblast cells adhere to the uterine epithelium by means of very special "connection complexes" resembling dense long-line, which, in the second stage, mediate degradation of the uterine epithelium and penetration of trophoblast cells through the epithelial basal lamina $(4,53)$. What is more, during this stage not only cellular digestion, but also symbiotic relationship between trophoblast and uterine cells may be established.

An interesting phenomenon of blastocystic ring attachment is the formation of the first contact points between its abembryonic pole and the uterine epithelium, carried out by a set of specialised trophoblast cells. These cells have no microvilli on their opposed to the uterus surface, the part of their cytoplasm associated with the contact points is devoid of organelles, and interestingly, they also have very special tubulo-canalicular systems. With the first contact points, a mutual relation and a pseudosymbiosis for a limited period are established between the blastocyst and uterine epithelium by means of this specialised cells.

We address two questions, fundamental in the understanding of cell signalling $(54,55)$ between the trophoblast and the uterine epithelium: $(i)$ is there a pseudosymbiotic recognition representing simply the sum of an implant (trophoblast) cell and a recepient (uterine epithelium) cell, and (ii) are the recognition signals responsible for this mutualism, and what is its correlation with the restricted periods of invasive cell interactions. The investigation of the phenomenon of pseudo- symbiont recognition, and the establishment and maintainance of a pseudosymbiosis thus need a particularly complex experimental system that raises considerable complications in the laboratory work (54-56)

The properties of implantive cells to recognize recepient cells, and control substance transfer and morphogenesis are different aspects of an interactive phenomenon. According to the present knowledge $(52,54,55,57,58)$, pseudosymbiosis could be investigated by studying the structure of the host tissues, the dynamics of their surfaces, and their molecular organisation throughout the interactions in the initial stage of preimplantation $(25,26)$. Understanding the signalling between these tissues reveals the existence of stimuli important for the establishment of reciprocal communication $(55,59)$. The exact role of these interactions and their correlation with signalling mechanisms remain to be established. Signalling between the blastocyst and its maternal tissue is generally presumed to be important for a successful establishment of pregnancy in mammals. In some species, it depends on molecular signals, particularly the ligand-receptor system represented by soluble molecules such as hormones recognized by specific protein or glycoprotein membrane receptors transducing the signal inside the cell $(22,25,28,60-62)$. Both the uterine and the blastocyst cells are known to secrete various soluble factors during the preimplantation period $(62,63)$. During the precontact phase, on day 5 after fertilization, some coated pits and very small vesicles were observed in the space between the two interacting tissues, suggesting exchange of information between them. It appeared that the metabolic capacity of the blastocystic and uterine epithelium cells participates in signalling by metabolizing or converting substances. Further, blastocystic cells may have an asymmetry in the location of enzymes, carriers, and receptors on maternal (outer) and fetal (basal) cell surfaces. This functional polarity reflects blastocystic cell metabolism, nutrient/ion transport as well as the signals carrying information for implant acceptance or rejection by the endometrium.

The cell surface glycoproteins, colloidal iron, and cationized ferritin, associated with the reduction in surface negative charge, are known for their effect on the initial stage of blastocyst implantation (64-68). The contact between the surface of both cell types may be an adherence type junction $(21,64,67,69$, 70). We described in details the areas effusion of trophoblast knobs with uterine epithelial cells at the beginning of the contact face of implantation. Our findings, in agreement with the electron microscopical results reported $(64,65,71)$, indicate the existence of fine structural alterations at the apical surface of uterine epithelial cells at the site of their first contact with the blastocystic trophoblast cells. Hypertrophy of uterine epithelial cells, forming the so called "uterine plaque" in the Rhesus monkey, are observed in the beginning 
of the precontact phase of implantation in the rat (72). Prior to implantation, the blastocysts differentiated into mural and polar trophoblast cells, and embryonic pole including embryoblast, polar trophoblast, and endodermal cells. Differentiation of the endoderm into visceral and parietal portions consisting of individual structures, stellate-like cells with numerous cytoplasmic projections and filopodia, were observed by scanning electron microscopy. Finally, during the implantation of blastocyst, two endodermal derivatives have been described under diverse conditions, each associated with a distinct function. During blastocyst differentiation, cell debris of different contents and size was observed in some blastomers, especially in the mural trophoblast cells forming the blastocystic ring. These ultrastructural findings raise a question about apoptotic cell death involvement in blastocystic differentiation (see 14).

\section{CONCLUSION}

- The cytological features of blastocystic ring cells suggest that they consist of different trophoblastic cell types. According to their structural features, they can be divided into several functional groups. Their basic functions seem to be: $(i)$ supporting, preventing, and feeding functions; (ii) signalling between blastocyst and uterine epithelium, and polarisation/ depolarisation functions, $(\mathrm{Hi})$ immunological acceptance or rejection, and secretion, (iv) establishment of contact between the implanting tissue and decidua via cytoplasmic membrane fusion, and $(v)$ a temporary pseudosymbiosis between these two interacting tissues.

\section{ACKNOWLEDGEMENT}

- Ismail Ustunel, Necdet Demir, and Erdogan Kocamaz contributed significantly to this work with their excellent technical assistance. This work was supported by the Research Found of Akdeniz University, grant No 88.103.04, andDAAD, Germany.

1. King A, Weillings V, Gardner L, Loke YW. Immunocytochemical characterisation of the unusual large granular lymphocytes in human endometrium throughout the menstrual cycle. Hum Immunol 1989; 24:195-205.

2. Demir R, Erbengi T. Development and three dimensional structure of early human placental villi. JScan Microsc 1992; 14: 69-70.

3. Demir R, Kaufmann P, Castellucci M, Erbengi T, Katowski A. Fetal vasculogenesis and angiogenesis in human placental villi. Acta Anat 1989; 136: 190-203.
4. Librach CL, Werb Z, Fitzgerald ML, ChiuK, CorwinNM, Esteves RA et al. 92-kD type IV collagenase meditates invasion of human cytotrophoblasts. J Cell Biol 1991; 113: 437-449.

5. Redman CWG. Cytotrophoblasts: masters of disguise. Nat Med 1997; 3: 610-811.

6.. Denker HW. Cell biological views of embryo implantation. Turk J Med Sci 1995; Suppl: 1-12.

7. Enders AC, Hendrickx AG, Schlafke S. Differentiation of the embryonic disc, amnion, and yolk sac in the Rhesus monkey. Am J Anat 1986; 177: 161-185.

8. Denker H-W, Enders AC, Schlafke S. Bizarre hypertrophy of vascular endothelial cells in rhesus monkey endometrium: experimental induction and electron microscopical characteristics. Verh Anat Geslf 1985; 79: 545-548.

9. Hearn JP. The embryo-maternal dialogue during early pregnancy in primates. J Reprod Fertil 1986; 76: 809819.

10. Owiti GEO, Cukierski M, Tarara RP, Enders AC, Hendrickx AG. Early placentation in the African Green monkey (Cercopithecus aethiops). Acta Anat 1986; 127: 184-194.

11. Tarar R, Enders AC, Hendrikcx AG. Early implantation and embryonic development of the baboon: stage 5,6 and 7. Anat Embryol 1987; 176: 267-275.

12. Enders AC, Schlafke S. Implantation in non-human primates and in the human. In: Comparative primate biology, Vol. 3: Reproduction and development. Alan RLiss, New York, 1989; 291-310

13. King A, Loke YW. Uterine large granular lymphocytes: a possible role in embryonic implantation? Am J Obstet Gynecol 1990; 162: 308-310.

14. Bamberger A-M, Schulte HM, Thuneke I, Erdmann I, Bamberger CM, Asa SL. Expression of the apoptosisinducing Fas ligand (FasL) in human first and third trimester placenta and choriocarcinoma cells. J Clin Endocrinol Metab 1997; 82: 3173-3175.

15. Kauma S, Huff T, Kristal G, Ryan J, Takacs P, Turner T. The expression of stem cell factor and its receptor, $c$-kit in human endometrium and placental tissues during pregnancy. J Clin Endocrinol Metab 1996; 81: 12611266. 
16. Lieser R, Denker H-W. The dynamic structure of rabbit blastocyst coverings. II. Ultrastructural evidence for a role of the trophoblast in neozona formation. Anat Embryo! 1988; 179: 129-134.

17. Marx M, Winterhager E, Denker H-W. Penetration of the basal lamina by processes of the uterine epithelial cells during implantation in the rabbit. In: Denker H-W, Aplin JD, editors. Trophoblast research. Plenum Press, New York, 1990; 417-430.

18. Welsh AO, Enders AC. Light and electron microscopic examination of the mature decidual cells of the rat with emphasis on the antimesometrial decidua and its degeneration. Am J Anat 1985; 172: 1-29.

19. Fleming T P, Warren PD, Chisholm JC, Johnson MH. Tropoectodermal processes regulate the expression of totipotency within the inner cell mass of the mouse expanding blastocyst. J Embryol Exp Morphol 1984; 84:63-90.

20. Demir R, Ustunel I. Distribution of some enzymes in implantation site of pregnant rats. Placenta 1989; 10: 457-458.

21. Demir R, Ustunel I, Demir N. Light and electron microscopical observations on cellular interactions during initial stages of implantation and trophoblastic invasion in rats. Placenta 1989; 10: 464-465.

22. Edwards RG Physiological and molecular aspects of human implantation. Hum Reprod 1995; 10 (Suppl 2): 113.

23. Psycohoyos A, Nikas G,Gravanis A The role of prostaglandins in blastocyst implantation. Hum Reprod 1995; 10 (Suppl 2): 30-42.

24. Bhatt H, Brunei LJ, Stewart L. Uterine expression of leukemia inhibitory factor coincides with the onset of blastocystic implantation. Proc NatlAcad Sci USA 1991; 88:11408-11412.

25. Harvey MB.Leco KJ, Accelluna-Panlilo MY, Zhang X, Edwards RD, Shultz GA. Role of growth factors during preimplantation development. Hum Reprod 1995; 10: 712-718.

26. Loke YM, Gardnr L, Burland K, King A. Laminin in human trophoblast-decidua interaction. Hum Reprod 1989; 4:457-463.
27. Tabibzadelh S, Zupi E, Babaknia A, Lin R, Marconi D, Romanini C. Site and menstrual cycle dependent expression of proteins of tumor necrosis factor (TNF)receptor family, and $b c l-2$ oncoprotein and phasespecific production of TNF-oc in human endometrium. Hum Reprod 1995; 10: 227-286.

28. Denker H-W. Trophoblast-endometrial interactions at embryo implantation: a cell biological paradox. Trophobl Res 1990; 4: 3-29.

29. Bell SC, Fazleabas AT, Verhage HG. Comparative as pects of secretory proteins of the endometrium and decidua in the human and non-human primates. In: Yoshinaga K, editor. Blastocyst implantation. Adams, Boston, 1989; 151-162.

30. le-Ming S, Kurman RJ. Expression of melanoma cell adhesion molecule in intermediate trophoblast. Lab In vest 1996 ; 75:377-388.

31. Loke YW, King A. Immunology of pregnancy: quo vadis? Hum Reprod 1989; 4: 613-615.

3 2. Enders AC, Lantz KC, Schlafke S. The morula-blastocyst transition in two old world primates: the baboon and Rhesus monkey. J Med Primatol 1990; 19: 725-747.

33. Leiser R. Ultrastructural aspects of implantation. In: Semm K, Mettler L, editors. Human reproduction. Excerpta Medica, Amsterdam, 1981; 378-382.

34. Welsh AO, Enders AC Chorioallantoic placenta formation in the rat: I. Luminal epithelial cell death and extracellular matrix modifications in mesometrial regions. Am J Anat 1992; 2: 215-231.

35. Welsh AO, Enders AC. Chorioalantoic placenta formation in the rat: II. Angiogenesis and blood circulation in the mesometrial regions of the implantation chamber prior to placenta formation. Am J Anat 1992; 4: 347-365.

36. DemirR, DemirN, UstunelI, ErbengiT. Cellular identification in blastocystic ring at the beginning of implantation in rats. Placenta 1991; 12: 380.

37. Johnson MH. Manipulation of early mammalian development: what does it tell us about cell lineages? In: Gwatkin RBL, editor. Developmental biology. Plenum Press, New York, 1986; 279-296.

38. Levy JB, Johnson MA, Goodall H, Maro B. The timing 
compaction: control of a major developmental transition in mouse early embryogenesis. J Embryo! Exp Morphol 1986; 95: 213-237.

39.

FisherB,JungT,HegeleHartungC,BeierHM.Developme nt of preimplantation rabbit embryos in uterine flushing supplemented culture media. Mol Reprod Dev 1990; 27:216-223.

40. Enders AC. Morphological manifestations of maturation of the blastocyst. In: Yoshinaga K, Mori T, editors. Development of preimplantation embryos and their environment. Alan R Liss, New York, 1989; 211-223.

41. Enders AC, King FB. Formation and differentiation of extraembryonic mesoderm in the rhesus monkey. Am $J$ Anat 1988; 181: 327-340.

42. Demir R, Demir AY, Goerge K, Erbengi T, Ustunel I, Demir $\mathrm{N}$ et al. Fine structure of cellular connections between trophoblast cells of blastocyst and uterinal epithelium in rats. In: Magies-Magies L, Rodrigez MI, Rios A, Arias JM, editors. Electron microscopy 92, Vol.3: Biological Sciences, Granada, 1992; 829-830.

43. Demir R, Demir AY, Kohnen G, Kaufmann P. Cellular diversity of human placental vessel wall. In: Catravas JD, Callow AD, Ryan US, editors. Vascular endothelium. Responses to injury. Plenum Press, New York, 1996; 265-266.

44. Swenson KI, Jordon RJ, Bayer EC, Paul DL. Formation of gap junction by expression of conexins in Xenopus oocytes cell pairs. Cell 1989; 57:145-155.

45. Pitts JD. Junctional communication: the role of communication compartments in complex multicellular organisms. In: Robards AW, Jongsma HH , Lucas WJ, Pitts J, Spray D, editors. Parallels in cell to cell junctions in plants and animals. Springer Verlag, Berlin, 1990; 58-79.

46. Pitts JD, Finbow ME, Kam E. Junctional communication and cell differentiation. Br J Cancer 1988; 58: 52-57.

47. Kam E, Pitts JD. Paterns of Junctional communication in skin. J Invest Dermatol 1986; 87: 748-753.

48. MasuzakiH, OgawaY, SagawaN, HosodaK, Matsumoto $\mathrm{T}$, Mise $\mathrm{H}$ et al. Nonadipose tissue production of leptin: leptin as a novel placenta-derived hormone in humans. Nat Med 1997; 3: 1029-1033.
49. Kam E, Pitts JD. Tissue specific regulation of Junctional communication in the skin of foetuses homozygous for the repeated epilation mutation. Development 1989; 107: 923-929.

50. Serras F, van den Biggelaar JAM. Progressive restrictions in gap Junctional communication during development. In: Robards AW, Jongsma H, Lucas WJ, Pitts J, Spray D, editors. Parallels in cell to cell junctions in plants and animals. Springer Verlag, Berlin, 1990; 85-

51. Finbow ME, Thompson P, Keen J, Jackson P, Eliopuolos E, Meoghe $\mathrm{R}$ et al. A structural analysis of the molecules involved in gap Junctional communication. In:Robards AW, Jongsma H, Lucas WJ, Pitts J, Spray D, editors. Parallel in cell to cell junctions in plants and animals. Springer Verlag, Berlin,1990; 136-148.

52. Paul D. Molecular cloning of cDNA for rat liver gap junction protein. J Cell Biol 1986; 103: 123-134.

53. Schlafke S, Welsh AO, Enders AC. Penetration of the basal lamina of the uterine luminal epithelium during $>a$ implantation in the rat. Anat Rec 1985; 212: 47-56.

54. Nuti MP, Pasti MB, Sourartini A. Aplication of genetic engineering to symbiontology in agriculature. In: Scannerini S, Smith P, Bonfante-Fasolo V, GianninazziPearson V, editors. Cell to cell signals in plant, animal andmicrobialsymbiosis. Springer Verlag,Berlin, 1988;

55. Smith DC. Concepts leading to an understanding of recognition and signalling between hosts and symbionts. In: Scannierini S, Smith DC, Bonfante-Fosolo P, Gianinazzi-Pearson V, editors. Cell to cell signals in plant, animal and microbial symbiosis. Springer Verlag, Berlin, 1988; 347-359.

56. Monsigny M, Roche AC, Kieda C, Mayer R, Midoux P. Peptide and carbonhydrate moieties as molecular signals in animal cell recognation. In: Scannerini S, Smith DC, Bonfante-Fasolo P, Gianinazzi-Pearson V, editors. Cell to cell signals in plant, animal and microbial symbiosis. Springer Verlag, Berlin 1988; 237-257.

5 7. Heinde R. Factors produced by symbiotic marine in vertebrate which affect translocation between the symbiont. In: Scannerini S, Smith DC, Bonfante-Fasolo $\mathrm{P}$, Gianinazzi-Pearson V, editors. Cell to cell symbiosis in plant, animal and microbial Symbiosis. Springer Verlag, Berlin, 1988; 311-324. 
58. Scannerini S. Micorrhizal symbiosis 2: the process. Dev Biol 1985; 78: 546-553.

59. Goldbeter A. Theoretical models for cell to cell signalling. In: Neuhoff V, Friend J, editors. Cell to cell signalling in plants and animals. Springer Verlag, Berlin, 1991; 291-314.

60. Iwakura Y, Nozaki M. Role of cell surface glycoproteins in the early development of the mouse embryo. In: Yoshinaga K, Mori T, editors. Development and preimplantation embryos and their environment. Alan R Liss, New York 1989; 199-210.

61. Jayatilak PG, Puryear TK, Herz Z, Fazleabas A, Gibori G. Expression of mRNAs and synthesis of proteins by rat antimesometrial and mesometrial decidua. In: Yoshinaga $\mathrm{K}$, editor. Blastocyst implantation. Adams, Boston, $1989 ; 145-150$.

62. Weitlauf HM. Embryonic signalling at implantation in the mouse. Prog Clin Biol Res 1989; 294: 359-376.

63. Baker DJ, Nieder GL. Interferon activity is not detected in blastocyst sections and does not induce decidualization in mice. J Reprod Fertil 1990; 88: 307-313.

64. Bevilacqua EM, Abrahamsohn PA. Trophoblast invasion during implantation of the mouse embryo. Arch Biol 'Med $\operatorname{Exp} 1989 ;$ 22: 107-118.

65. Enders AC, Liu IKM, Lantz, KC, Schlafke S. Loss of polar trophoblast during differentiation of the blastocyst of the horse. J Reprod Fertil 1988; 83: 447-460.

66. Enders AC, Schlafke S, HubbardNE, MeadRA. Morphological changes in the blastocyst of the western spotted skunk during activation from delayed implantation. Biol Reprod 1986; 34: 423-437.

67. Demir G, Kocamaz E, Demir R. Structural and functional aspects of the uterine glandular epithelium during first twenty eight days of gestation. Turk J Med Sci 1995;

68. Fisher B. Effects of asynchrony on rabbit blastocyst development. J Reprod Fertil 1989; 86: 479-491.

69. Demir G, Ustunel I, Demir R. A morphometric and electron microscopic study on blastocyst and uterine epithelium interaction during implantation in rat. TurkJ Med Sci 1995; Suppl: 74-75.

70. Demir AY, Demir N, Kosanke G, Demir R. Collagen III and IV detection in the human placenta by immunohisto-, chemistry in accordance with ultrastructural findings. TurkJ Med Sci 1995; Suppl: 75-76.

71 . Bulmer JN, Smith J, Morrison L, Wells M. Maternal and fetal cellular relationship in the human placental basal plate. Placenta 1988; 9: 237-246.

72. Enders AC. Current topic: structural responses of the primate endometrium to implantation. Placenta 1991; 